\title{
Infrared thermography and Doppler ultrasonography to evaluate the effects of scrotal insulation on testicular blood flow dynamics in bulls
}

\section{Termografia infravermelho e ultrassonografia Doppler na avaliação dos efeitos da insulação escrotal sobre o fluxo sanguíneo testicular em touros}

\author{
Flávio Antônio Barca Junior ${ }^{1 *}$; Celso Koetz Junior ${ }^{2}$; Patrícia da Cruz Fávaro3; \\ Gabriel Ribas Pereira ${ }^{4}$; Silvio Renato Oliveira Menegassi ${ }^{5}$; Fábio Morotti ${ }^{6}$; Victor \\ Hugo Gonçalves Galdioli³; Anne Kemmer Souza ${ }^{7}$; Júlio Otávio Jardim Barcellos; \\ Marcelo Marcondes Seneda ${ }^{6}$
}

\section{Highlights:}

Superficial temperature of the scrotum and testicular blood flow in bulls is shown.

Temperature at the different time in the insulated and control animals is shown.

The PI and RI did not show any significant difference after the insulation.

The velocity of blood flow was higher in the M10 of the insulated animals.

Quality of the semen was higher in all twelve collections from the control group.

\begin{abstract}
The aim of this study was to evaluate the dynamics of the scrotal temperature, sperm quality and testicular blood flow by using infrared thermography and Doppler ultrasonography in bulls submitted to scrotal insulation. Braford bulls $(\mathrm{n}=8)$ at 18 months of age, were assigned into the following groups: insulated for $72 \mathrm{~h}(\mathrm{G} 72 ; \mathrm{n}=2), 96 \mathrm{~h}(\mathrm{G} 96, \mathrm{n}=2), 120 \mathrm{~h}(\mathrm{G} \mathrm{120,n}=2)$, and control animals (CON; $\mathrm{n}$ $=2$ ) that remained without insulation. Infrared thermography and Doppler ultrasonography parameters were measured at four different time points: immediately after the scrotal insulation (M0), within 10 $\min$ (M10), $30 \mathrm{~min}$ (M30) and $60 \mathrm{~min}$ (M60) after scrotal insulation. The sperm quality was evaluated weekly (S1/S12). The data were analyzed by ANOVA, t-test (paired) and Pearson's correlation with a significance level of $5 \%$. None of the observed variables were different between the insulated groups (P $>0.05$ ). Insulated animals showed higher scrotal temperature in M0 compared to that in the M10, M30 and M60 periods $(\mathrm{P}<0.05)$. There was no difference in the pulsatility and resistive indexes after scrotal
\end{abstract}

\footnotetext{
1 Prof. Dr., Curso Medicina Veterinária, Universidade Norte do Paraná, UNOPAR, Arapongas, PR, Brasil. E-mail: flavio.barca@ unopar.br

2 Prof. Dr., Mestrado em Saúde e Produção de Ruminantes, UNOPAR, Arapongas, PR, Brasil. E-mail: celsokoetzjr@yahoo.com.br

3 Discentes, Mestrado em Saúde e Produção de Ruminantes, UNOPAR, Arapongas, PR, Brasil. E-mail: patricruzfavaro@hotmail. com; vgaldioli@hotmail.com

4 Pesquisador, Mestrado em Saúde e Produção de Ruminantes, UNOPAR, Arapongas, PR, Brasil. E-mail: gabrielribaspereira@ gmail.com

5 Pesquisador, Universidade Federal do Rio Grande do Sul, UFRGS, Porto Alegre, RS, Brasil. E-mail: programa.paat@gmail.com

6 Profs. Drs., Laboratório de Reprodução Animal, REPROA, DCV/CCA, Universidade Estadual de Londrina, UEL, Londrina, PR, Brasil. E-mail: fabiomorotti@uel.br; marcelo.seneda@uel.br

7 Discente, Doutorado em Ciência Animal, UEL, Londrina, PR, Brasil. E-mail: annekemmer@hotmail.com

8 Prof. Dr., Universidade Federal do Rio Grande do Sul, UFRGS, Porto Alegre, RS, Brasil. E-mail: julio.barcellos@ufrgs.br

* Author for correspondence
} 
insulation. However, blood flow velocity was higher in M10 compared to that in the M0, M30 and M60 periods $(\mathrm{P}<0.05)$. The sperm quality was higher $(\mathrm{P}<0.05)$ in all twelve collections from the control group compared with the insulated groups. Scrotal insulation resulted in changes in the sperm quality, scrotal temperature and testicular blood flow velocity.

Key words: Heat stress. Testicular blood flow. Thermotolerance.

\section{Resumo}

O objetivo deste estudo foi avaliar a dinâmica da temperatura escrotal, a qualidade espermática e o fluxo sanguíneo testicular utilizando a termografia infravermelho e a ultrassonografia Doppler em touros submetidos a insulação escrotal. Touros Braford $(\mathrm{n}=8)$ aos 18 meses de idade, foram distribuídos nos

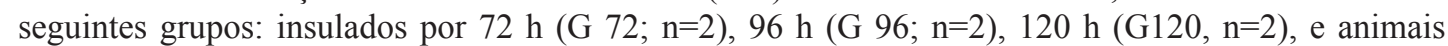
controle $(\mathrm{CON} ; \mathrm{n}=2)$ que permaneceram sem insulação. Os parâmetros de termografia infravermelha e ultrassonografia Doppler foram medidos em quatro diferentes momentos: imediatamente após a insulação escrotal (M0), aos 10 min (M10), 30 min (M30) e 60 min (M60) após a insulação escrotal. A qualidade espermática foi avaliada semanalmente (S1 / S12). Os dados foram analisados por ANOVA, teste t (pareado) e correlação de Pearson com nível de significância de 5\%. Nenhuma das variáveis observadas foi diferente entre os grupos insulados $(\mathrm{P}>0,05)$. Os animais insulados apresentaram maior temperatura escrotal em M0 quando comparados aos M10, M30 e M60 (P < 0,05). Não houve diferença nos índices de pulsatilidade e resistividade após a insulação escrotal. No entanto, a velocidade do fluxo sanguíneo foi maior em M10 em relação aos períodos M0, M30 e M60 (P < 0,05). A qualidade espermática foi maior $(\mathrm{P}<0,05)$ em todas as doze coletas do grupo controle em comparação com os grupos insulados. A insulação escrotal resultou em mudanças na qualidade espermática, temperatura escrotal e na velocidade do fluxo sanguíneo testicular.

Palavras-chave: Estresse calórico. Fluxo sanguíneo testicular. Termotolerância.

\section{Introduction}

In bulls, adequate sperm production occurs only when the testes are kept at 4 to $5^{\circ} \mathrm{C}$ below body temperature (Brito, Silva, Barbosa, \& Kastelic, 2004; Waites, 1970). This temperature control occurs in conjunction with efficient physiological heat exchange actions, such as the contractile activity of the cremaster muscle and the countercurrent blood flow established between the testicular artery and the pampiniform plexus veins (Brito et al., 2004; Kastelic, 2014; Kastelic, Coulter, \& Cook, 1995).

Clinically, male reproductive failure may occur with reduced seminal quality due to the low ejaculate volume, changes in sperm concentration (oligozoospermia or azoospermia), decreased sperm motility and vigor, as well as a high proportion of sperm cells with morphological abnormalities (Brito et al., 2002). Such failures are commonly found in breeding herds where thermoregulation is compromised (Lunstra \& Coulter, 1997). However, the severity of these changes depends mainly on the time at which the factors responsible for temperature increases remain active (Horn, Moraes, \& Galina, 1999). In some situations, the thermoregulation mechanism can be severely affected, leading to complete suppression of spermatogenesis, drastically compromising herd fertility (Freneau, Chenoweth, Ellis, \& Rupp, 2010).

Physiological mechanisms or pathological processes lead to the elevation of the scrotal temperature (Bustos-Obregon, 2007; Polguj, Jędrzejewski, \& Topol, 2010). Infrared thermography is an analysis resource able to verify the different nuances of the evaluated surface temperature. At present, this technique has been used because it is not invasive, it is performed in real time, it is relatively inexpensive, and it helps to diagnose many diseases (Alsaaod et al., 2014; Chou \& Yao, 2009; Knížková, Kunc, Gürdil, Pinar, 
\& Selvi, 2007). In addition, temperature dynamics have been studied to better understand the physiology of certain organs (Lunstra \& Coulter, 1997; Menegassi et al., 2015).

For a better understanding of the physiological aspects, besides being an excellent diagnostic tool especially in the care of the testicles, ultrasonography has been used in the reproductive evaluation of bulls (Kastelic \& Brito, 2012). The advancement of this technology allowed a velocimetric Doppler evaluation (Herzog \& Bollwein, 2007) that facilitates the understanding of the blood dynamics in several organs, including the testicles.

The experimental insulation of the scrotum simulates heat stress in the scrotum by increasing the local temperature (Brito, Silva, Barbosa, Unanian, \& Kastelic, 2003; Vogler, Bame, DeJarnette, McGilliard, \& Saacke, 1993). It is the ideal methodology to evaluate the morphological and physiological changes occurring in the testes due to the alteration of the scrotal temperature in cattle (Fernandes, Dode, Pereira, \& Silva, 2008; Pezzini, Sartori, Silva, McManus, \& Mariante, 2006) and other species (Moreira, Moura, \& Araújo, 2001). The period of animal residence during provoked testicular insulation varies from 48 to 120 hours (Pezzini et al., 2006; Vogler et al., 1993); however, Bonilla et al. (2013) do not recommend periods shorter than 72 hours.

The objective of the present study was to evaluate the thermodynamics of the surface temperature of the scrotum, the hemodynamics of the supratesticular artery and the evaluation of the semen in bulls submitted to scrotum insulation.

\section{Material and Methods}

\section{Ethics statement}

All animal procedures used in this study were approved by the local Animal Ethical Committee from the State University of Londrina (UEL; $18656 / 2014 / 58)$.

\section{Animals and experiment location}

This experiment was carried out from October to December 2014 at a farm in Londrina, Paraná, Brazil (latitude $23^{\circ} 30^{\prime} 10^{\prime \prime} \mathrm{S}$ and longitude $51^{\circ}$ 14' 10" W). The climate at Londrina, according to the Köppen classification, is $\mathrm{Cfa}$ (humid subtropical climate), with average temperatures of 16 to $17^{\circ} \mathrm{C}$ in the winter (June to September) and 27 to $28^{\circ} \mathrm{C}$ in the summer (December to March). The relative humidity is $75-80 \%$, characterized by rainfall during all the seasons, with droughts occurring in the winter, and a mean annual rainfall of 1400 to 1600 mm (Caviglione, Kiihl, Caramori, \& Oliveira, 2000). The study was conducted in eight Braford bulls (3/8 Nellore - 5/8 Hereford) with a mean weight of $531.28 \pm 23.45 \mathrm{~kg}$, a scrotal circumference of $38.63 \pm 2.83 \mathrm{~cm}$ and at 18 months of age. All the animals were previously evaluated, considered to be clinically healthy, and were kept in a pasture under a natural shade of Brachiaria brizantha (Marandú) with mineral supplementation and water ad libitum throughout the experimental period.

\section{Experimental design}

For this study, the animals were randomly divided into four distinct groups: the control group $(\mathbf{C O N}, \mathrm{n}=2)$ that was not submitted to scrotal insulation, insulated group $1(\mathbf{G} \mathbf{7 2}, \mathrm{n}=2)$ that remained insulated for 72 hours, insulated group 2 (G 96, n = 2) maintained under insulation for 96 hours and insulated group $3(\mathbf{G} \mathbf{1 2 0}, \mathrm{n}=2)$ with insulation for 120 hours. The number of animals and the time of insulation were established according to previous studies (Bonilla et al., 2013; Brito et al., 2003; Fernandes et al., 2008; Vogler et al., 1993).

The insulation was performed using disposable infant diapers (Size G, Pampers ${ }^{\circledR}$, P \& G, São Paulo, Brazil) covering the whole surface of the bulls' scrotums and adapted from the model proposed by Brito et al. (2003). Immediately afterward, the disposable diapers were covered and protected with cotton cloth bags $\left(\right.$ Debruns $^{\circledR}$, BG Maturano, Arapongas, Brazil). The insulating bags were placed 
on the different groups every $24 \mathrm{~h}$ starting with G120, thus allowing the removal of the insulation apparatuses in all the groups on the same day.

The superficial temperature of the scrotum was measured in the afternoon (1:00 p.m. - 5:00 p.m.) by the same evaluator using a FLIR thermograph model T440 (Flir Systems Inc., Wilsonville, USA) with a resolution of $0.01^{\circ} \mathrm{C}$, an optical resolution of 76,800 (320X240) pixels and an adjusted emission coefficient of 0.97 . The images were taken perpendicular to the scrotum with a distance of 1.5 meters as adapted from Menegassi et al. (2015). The images were interpreted using the Quick Report ${ }^{\circledR}$ software (Flir Systems Inc., Wilsonville, USA) after transferring to an $\operatorname{Ipad}^{\circledR}$ (Apple Inc, Cupertino, USA) and using the line methodology for the thermogram at the top and bottom of the scrotum. Immediately after assessing the scrotal temperature, the rectal temperature was measured using a flexible digital rod clinical thermometer (Jumbo, Incoterm, Porto Alegre, Brazil).

Subsequently, Doppler sonographic images were captured using a Sonoscape model A6V (SonoScape, DOMED, Valinhos, Brazil) ultrasonic device with linear transducer L741V (5-10 MHz) at a frequency of $7.5 \mathrm{MHz}$, according to Barca Junior et al. (2018).

Thermographic and color Doppler images were collected at four different periods: after the withdrawal of the insulating bag (M0), 10 minutes after withdrawal (M10), 30 minutes after withdrawal (M30), and 60 minutes (M60).

A total of twelve semen samples were collected from each animal weekly (S1 through S12) by electroejaculation using the Pulsator IV equipment (Lane Manufacturing Denver, USA). A probe with electrodes was inserted rectally and stimulated the animals by electric shocks (maximum $12 \mathrm{~V}$ ) until the semen sample was obtained; the animals were kept in their trunk during this process. The semen analysis of Turbidity (TURB), sperm motility (MOT), vigor (VIG), percentages of major defects (MD), minor defects $(\mathrm{mD})$ and total defects (TD) was performed according to Ruediger et al. (2016) and Chenoweth,
Hopkins, Spitzer and Larsen (2010). The criteria used for the spermatozoa evaluation were according to the Western Canadian Association of Bovine Practitioners (Chenoweth et al., 2010).

\section{Statistical analyses}

Data were presented by descriptive statistics in the form of mean and standard deviation. For the comparison between the different time measurements, in the case of dependent measures, we used the t-test for paired samples; and we used analysis of variance for the other comparisons. The Pearson's correlation was established for temperature data and Doppler measurements. The significance level used was $5 \%$ and the calculations were performed with the aid of the statistical package Minitab 18 (Minitab, State College, USA).

\section{Results}

The mean daily temperature, relative humidity and temperature and unit index (ITU) were $26.9 \pm$ $1.6^{\circ} \mathrm{C}, 57.8 \pm 9.26 \%$ and $75.05 \pm 1.41$, respectively. Data analyses revealed no significant differences between the animals in the insulated groups; therefore, the data referring to groups G72, G96 and G120 were analyzed together.

The comparison between the rectal temperature $\left(38.49 \pm 0.40^{\circ} \mathrm{C}\right)$ and the surface of the scrotum $\left(32.68 \pm 0.84^{\circ} \mathrm{C}\right)$ showed a significant difference $(\mathrm{P}$ $<0.001$ ), with the control group exhibiting a mean temperature of the skin surface $\left(31.7 \pm 0.14{ }^{\circ} \mathrm{C}\right)(\mathrm{P}$ $<0.05)$ at the temperature of the insulated animals $\left(33.00 \pm 0.69^{\circ} \mathrm{C}\right)$ at the time of removal of the insulating bag (M0). At the same time, no difference in the temperature of the scrotal surface was observed between the insulated groups $(\mathrm{P}>0.05)$.

The dynamics of the superficial temperature of the scrotum at the different time points in the insulated animals is shown in Table 1, with a difference between $\mathrm{M} 0$ and other time points $(\mathrm{P}$ $<0.05)$ but not between M10, M30 and M60 (P > 0.05) (Figure 1). 
Table 1

Temperature of the scrotal surface (TSO), pulsatility index (PI), resistivity index (RI) and mean velocity (MV) at different time points after scrotum insulation or in the control group.

\begin{tabular}{lcccc}
\hline Group & $\left.\operatorname{TSO}^{\circ} \mathrm{C}\right)$ & PI & RI & MV $\left(\mathrm{cm}^{\circ} \mathrm{s}^{-1}\right)$ \\
\hline Control (M0) & $31.07 \pm 0.14^{\mathrm{a}}$ & $0.25 \pm 0.06^{\mathrm{a}}$ & $0.34 \pm 0.04^{\mathrm{a}}$ & $13.09 \pm 0.19^{\mathrm{a}}$ \\
$\mathrm{M}^{\dagger}$ & $33.00 \pm 0.69^{\mathrm{b}}$ & $0.41 \pm 0.13^{\mathrm{a}}$ & $0.41 \pm 0.11^{\mathrm{a}}$ & $12.52 \pm 5.09^{\mathrm{a}}$ \\
${\mathrm{M} 10^{\dagger}}^{\dagger}$ & $30.20 \pm 1.37^{\mathrm{a}}$ & $0.23 \pm 0.10^{\mathrm{a}}$ & $0.28 \pm 0.06^{\mathrm{a}}$ & $17.11 \pm 4.22^{\mathrm{b}}$ \\
$\mathrm{M}^{\dagger}$ & $31.63 \pm 1.57^{\mathrm{a}}$ & $0.26 \pm 0.11^{\mathrm{a}}$ & $0.30 \pm 0.09^{\mathrm{a}}$ & $14.27 \pm 4.94^{\mathrm{a}}$ \\
${\mathrm{M} 60^{\dagger}}^{\dagger}$ & $30.65 \pm 1.04^{\mathrm{a}}$ & $0.30 \pm 0.15^{\mathrm{a}}$ & $0.33 \pm 0.14^{\mathrm{a}}$ & $14.30 \pm 2.91^{\mathrm{a}}$ \\
\hline
\end{tabular}

Different lowercase letters overlapped in the same column indicate significant difference $(\mathrm{P}<0.05)$.

† Group of insulated animals.

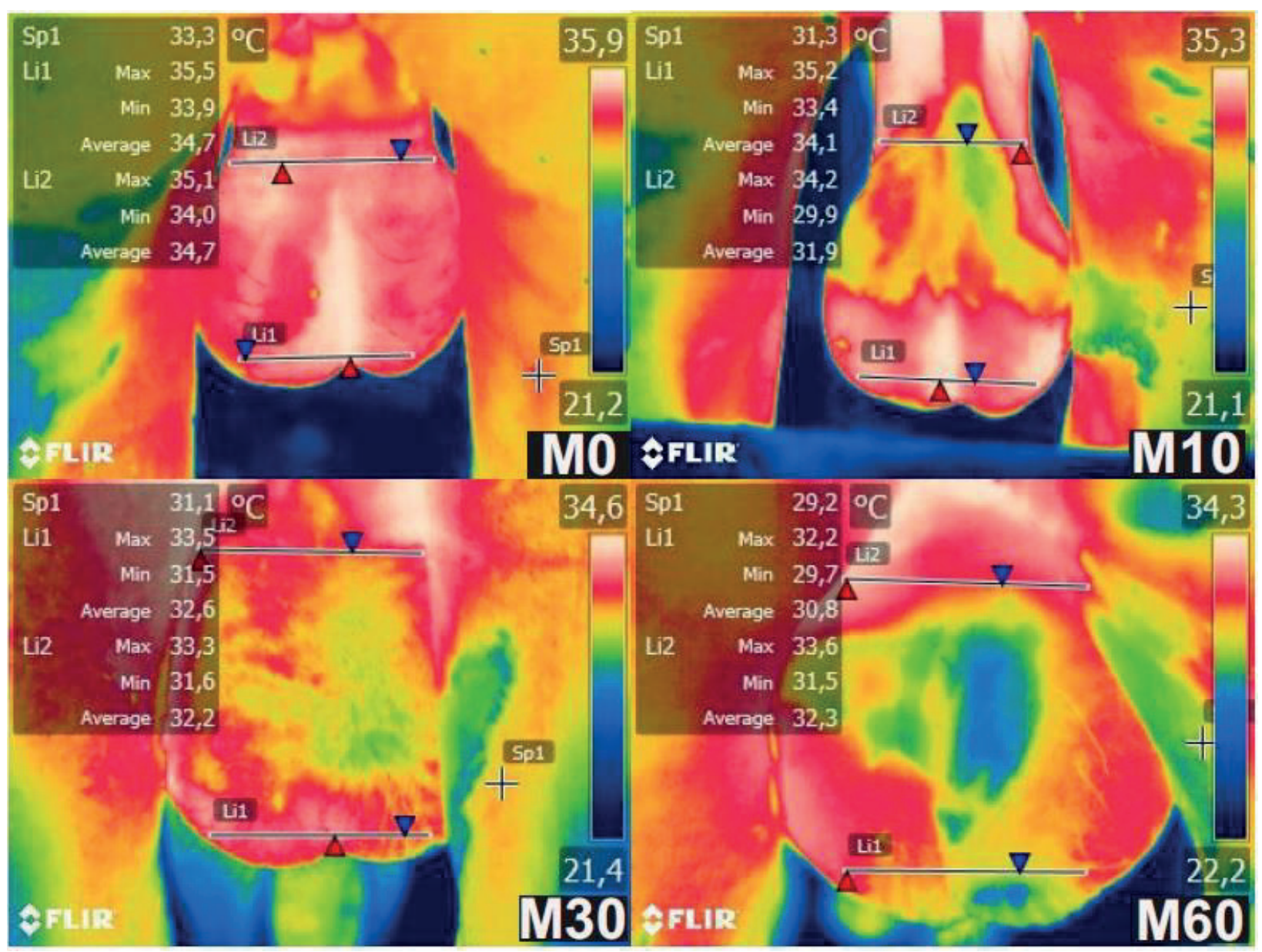

Figure 1. Thermographic image of the Braford bull scrotum at different time points (M0, M10, M30 and M60). The red areas represent higher temperatures when compared to the yellow, green or blue areas.

No changes were observed in any of the the information, it exhibited a tortuous anatomical evaluated animals in the ultrasound scans. In the pattern and waves with monophasic characteristics Doppler view, the supratesticular artery was easily (Figure 2). observed; although it was not difficult to collect 


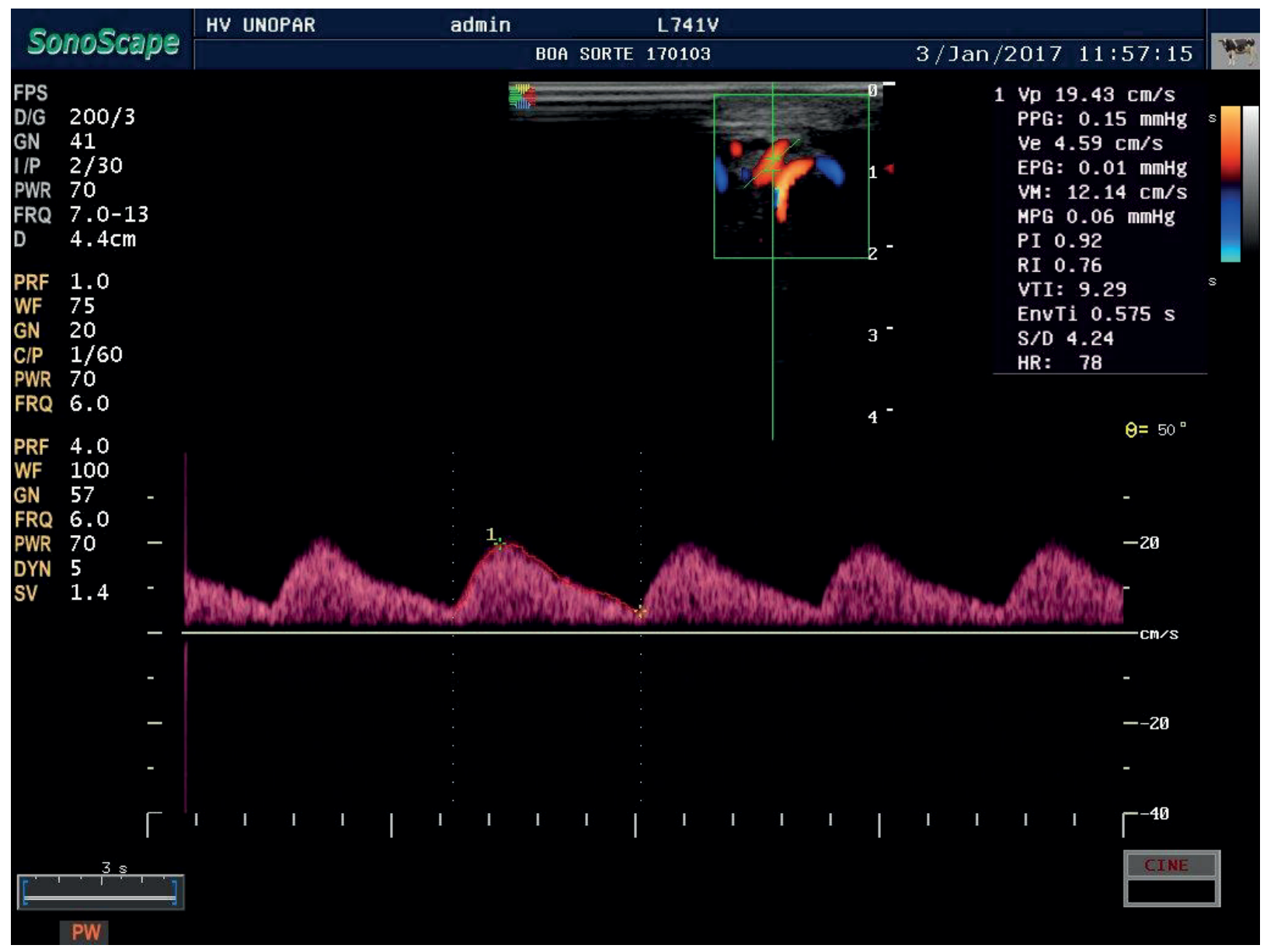

Figure 2. Doppler velocimetric analysis of the supratesticular artery of a Braford bull representing a single-phase wave pattern.

The PI and RI data did not show any significant difference $(\mathrm{P}>0.05)$ between the groups or between the different time measurements after the insulation. The mean values and their respective standard deviations are shown in Table 1.

The velocity of blood flow was higher $(\mathrm{P}<0.05)$ in the M10 of the insulated animals in relation to that of the other time points and in relation to that of the control group, which was similar $(\mathrm{P}>0.05)$ to the M0, M30 and M60 (Table 1). Among the possible variable correlations in the four-time points, PI and RI values presented a high correlation $(0.931$; $\mathrm{P}<$ $0.05)$.
The quality of the semen was higher $(\mathrm{P}<0.05)$ in all twelve collections from the control group when compared to the animals that went through the insulation process (Table 2 and Figure 3), and there was no significant difference between the groups of insulated animals (G 72, G 96 and G 120). In the sperm kinetics of the insulated animals, the poorest results were observed for S3 to S6 motility (4.2 to $34 \%$ ), vigor in S5 (0.5) and in the swirling between S3 and S5 (0.0 to 0.2$)$; in these respective collections, all animals were considered unfit for breeding according to the criteria determined by the CBRA (Colégio Brasileiro de Reprodução Animal [CBRA], 2013). 
Table 2

Motility (MOT), vigor (VIG), whirling (TURB), minor defects (mD), major defects (MD) and mean total defects (TD) collected at twelve weeks after insulation or in the control Braford bulls (mean and standard deviation)

\begin{tabular}{cccc}
\hline Group & Control & Insulated & p-value \\
\hline MOT & $82.08^{\mathrm{a}} \pm 6.38$ & $47.53^{\mathrm{b}} \pm 22.66$ & $<0.001$ \\
VIG & $3.71^{\mathrm{a}} \pm 0.40$ & $2.68^{\mathrm{b}} \pm 1.15$ & 0.02 \\
TURB & $3.70^{\mathrm{a}} \pm 0.54$ & $1.42^{\mathrm{b}} \pm 1.11$ & $<0.001$ \\
mD & $6.20^{\mathrm{a}} \pm 1.08$ & $12.65^{\mathrm{b}} \pm 3.19$ & $<0.001$ \\
MD & $3.77^{\mathrm{a}} \pm 1.15$ & $22.17^{\mathrm{b}} \pm 5.85$ & $<0.001$ \\
TD & $9.98^{\mathrm{a}} \pm 2.04$ & $34.86^{\mathrm{b}} \pm 6.16$ & $<0.001$ \\
\hline
\end{tabular}

Different lowercase letters overlapped on the same row indicate significant difference $(\mathrm{P}<0.05)$.
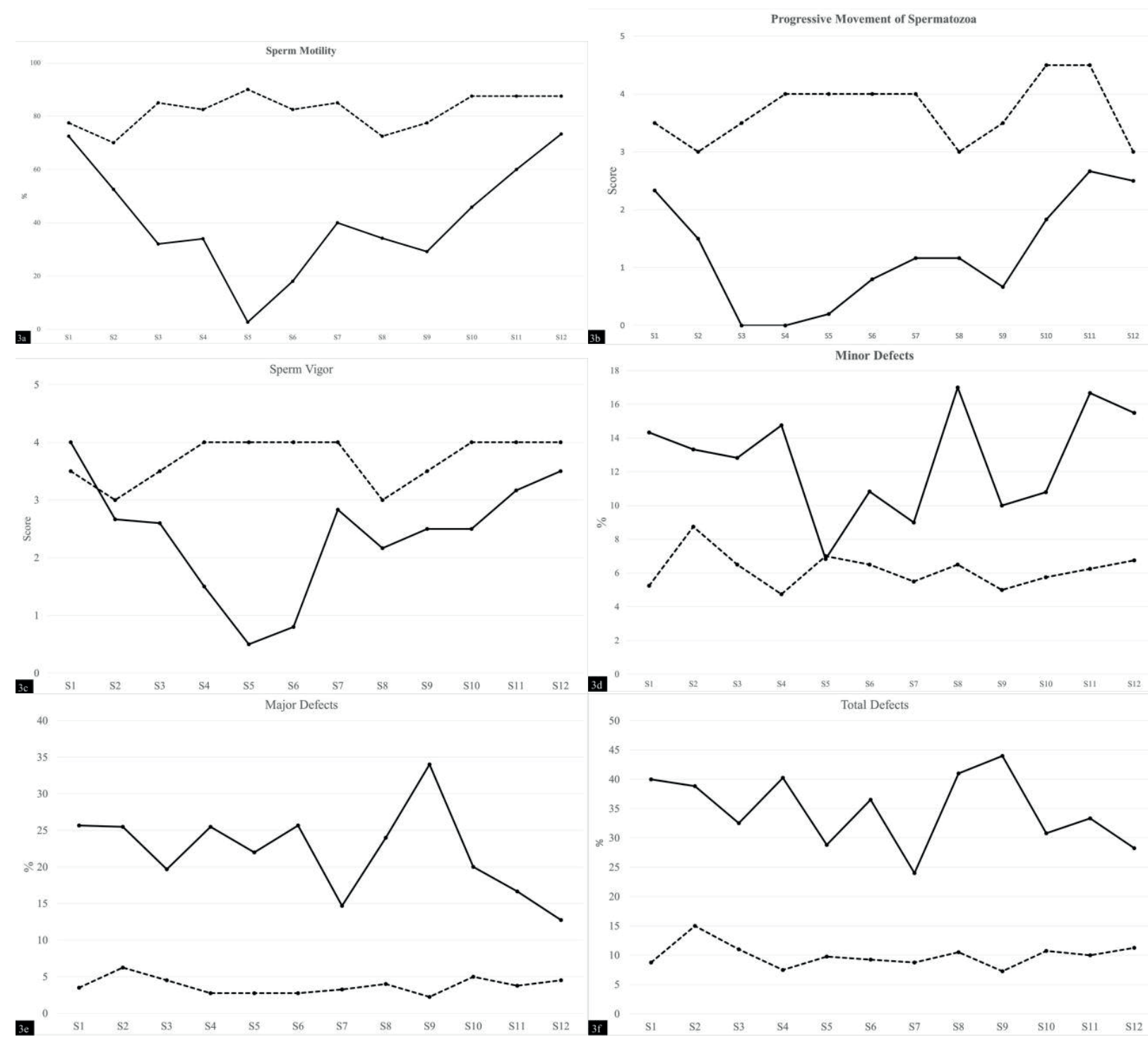

Figure 3. Weekly data evaluating motility (3a), progressive movement (3b), vigor (3c), minor defects (3d), major defects (3e), and average total defects (3f) collected twelve weeks (S1-S12) after insulation (continuous line) or in the control group (dashed line) of Braford bulls. 
For morphology, the lowest percentage of spermatozoa considered normal in the control group was S2 (85\%) and the highest in S9 (92.8\%). In the insulated animals, the highest percentage of normal spermatozoa was $71.8 \%$ in $\mathrm{S} 12$ and the lowest in S9 with $56 \%$. Even for the insulated animals, the highest frequency of minor defects occurred in S11 (16.67\%); the major defects occurred in the ninth week of collection (34\%), and the total defects were also observed in S9 (44\%).

\section{Discussion}

During insulation, the scrotal temperature reached values above the control group. However, ten minutes after the insulation ended, the temperature became similar to the control group, suggesting that this period is sufficient for heat dissipation due to the decrease of the surface temperature of the scrotum at M10. In addition, the Doppler mapping showed the velocity of the blood flow in the testes intensified shortly after insulation, although changes in the parameters of pulsatility and resistivity were not found between the animals of the control and insulated groups. These findings are relevant because they reinforce the thermoregulatory capacity of the testes in restoring the normal temperature in a short period.

The insulation procedure was efficient for heat retention by preventing dissipation and promoting an increase in the testicular temperature of the animals tested, which can be verified in M0 (Figure 1). In contrast to the duration, such temperature elevation may interfere with semen quality, which is reported from two days to six weeks after the onset of thermal stress (Barth \& Bowman, 1994); (Brito et al., 2003; Kastelic, Cook, Coulter, \& Saacke, 1996); (Alves et al., 2016; Brito et al., 2004; Fernandes et al., 2008; Kastelic, Wilde, Rizzoto, \& Thundathil, 2017; Rahman et al., 2011), and the results obtained by the present study. From the interruption of the injury, represented by the insulating bag, the physiological mechanisms of heat dissipation became highly efficient at reducing the scrotal temperature in a short period.

The reactivation of the thermoregulatory mechanisms resulted in a greater need for blood supply, which plays an important role in the heat exchange in the pampiniform plexus (Kastelic, 2014); this finding was also verified by Barros Adwell et al. (2018) who observed the highest testicular blood flow with increasing ambient temperature. This higher velocity of blood flow was verified in M10. Although no differences $(\mathrm{P}>0.05)$ were found for PI and RI at the different time points, their values in M10 would justify the increased blood flow (Batissaco et al., 2013).

The changes in semen quality were very evident in the group of insulated animals, and this process led to an increase in abnormal spermatozoa, as observed in studies conducted in the warm summer months in extensive bulls (Menegassi et al., 2015; Parkinson, 1987; Vogler et al., 1993). On the other hand, the semen samples collected from the control bulls showed no variation during the experimental period, maintaining the number of normal spermatozoa as observed in other studies $(78 \%$ to 94\%) (Barth \& Bowman, 1994).

In our study, the increase in testicular temperature in insular bulls caused mainly spermatozoa with a folded tail and the presence of cytoplasmic drops (Brito et al., 2003; Rahman et al., 2011) confirmed the findings of Setchell (1978) and Barth \& Oko (1989) that germ cells have different sensitivities regarding thermal stress. Spermatogonia present higher resistance to heat, whereas spermatocytes and spermatids are more sensitive demonstrating that the specific sperm alterations vary according to the insulation time to which the animal is submitted.

Local hyperthermia results in thermal stress increasing the level of cortisol in the animal's body and interfering in the spermatogenesis performed by endocrine mechanisms, specifically in the release of LH and testosterone production (Prabhakar, Chimbombi, Malmgren, Fredriksson, \& Madej, 
1990; Welsh \& Johnson, 1981). It was believed that increased testicular temperature would lead to an increase in the metabolic rate, oxygen consumption and consequently tissue hypoxia, interfering with sperm motility and morphology (Hamilton et al., 2016; Paul, Teng, \& Saunders, 2009; Setchell, 1998). However, Kastelic et al. (2017) demonstrated that hyperoxia did not prevent the damage induced by thermal stress on spermatozoa, indicating that changes in motility and morphology occurred only by hyperthermia and not by testicular hypoxia.

Thermographic imaging may provide a qualitative and quantitative map of temperature on the testicular surface and may be related to blood flow (Ammer, 2008); however, recent experiments (Menegassi et al., 2016) have shown that this test has a low correlation with spermatic morphology. More studies are needed to improve the methods of interpretation of scrotal temperature patterns and to confirm the correlation with semen quality and fertility characteristics in bulls (Menegassi et al., 2017).

The insulation process results in loss or damage of the homeostatic balance of testicular thermoregulation leading to several physiological changes. However, when the stress factor ceases, the organism seeks to recover it with the greatest possible agility (Brito et al., 2003; Setchell, 2006).

\section{Conclusions}

The results in this study confirm that scrotal insulation for up to 120 hours caused alterations in temperature, seminal quality and velocity of the testicular blood flow. The thermoregulatory mechanisms were efficient in normalizing the scrotal temperature and the testis blood velocity in less than 30 minutes. In addition, both infrared thermography and Doppler ultrasonography prove to be effective methods for monitoring the dynamics of the scrotal temperature and testicular blood flow in bulls submitted to scrotal insulation.

\section{Acknowledgments}

This work was supported by The Brazilian Council of Scientific and Technological Development (Project CNPq/Universal No. 430900/2016-3); The Coordination for the Improvement of Higher Education Personnel/CAPES, Brazil (Project PNPD/CAPES - UNOPAR); and UNOPAR/Kroton Educacional.

\section{Conflict of interest}

The authors declare that they have no conflict of interest.

\section{References}

Alsaaod, M., Syring, C., Dietrich, J., Doherr, M. G., Gujan, T., \& Steiner, A. (2014). A field trial of infrared thermography as a non-invasive diagnostic tool for early detection of digital dermatitis in dairy cows. The Veterinary Journal, 199(2), 281-285. doi: 10.1016/j.tvj1.2013.11.028

Alves, M. B. R., Andrade, A. F. C. D., Arruda, R. P. D., Batissaco, L., Florez-Rodriguez, S. A., Oliveira, B. M. M. D.,... Celeghini, E. C. C. (2016). Recovery of normal testicular temperature after scrotal heat stress in rams assessed by infrared thermography and its effects on seminal characteristics and testosterone blood serum concentration. Theriogenology, 86(3), 795-805.e792. doi: 10.1016/j. theriogenology.2016.02.034

Ammer, K. (2008). The Glamorgan protocol for recording and evaluation of thermal images of the human body. Thermology International, 18(4), 125-144.

Barca, F. A. Jr., Koetz, C. Jr., Fávaro, P. d. C., Pereira, G. R., Morotti, F., Menegassi, S. R. O.,... Seneda, M. M. (2018). Effect of breed on testicular blood flow dynamics in bulls. Theriogenology, 118(1), 16-21. doi: 10.1016/j.theriogenology.2018.05.022

Barros Adwell, C. M. Q., Brito, L. F. C., Oba, E., Wilde, R. E., Rizzoto, G., Thundathil, J. C., \& Kastelic, J. P. (2018). Arterial blood flow is the main source of testicular heat in bulls and higher ambient temperatures significantly increase testicular blood flow. Theriogenology, 116, 12-16. doi: 10.1016/j. theriogenology.2018.04.022 
Barth, A. D., \& Bowman, P. A. (1994). The sequential appearance of sperm abnormalities after scrotal insulation or dexamethasone treatment in bulls. The Canadian Veterinary Journal, 35(2), 93-102.

Barth, A. D., \& Oko, R. J. (1989). Abnormal morphology of bovine spermatozoa. Ames: Iowa State University Press.

Batissaco, L., Carvalho Celeghini, E. C., Pinaffi, F., de Oliveira, B. M. M., Andrade, A. de, Serrano Recalde, E., \& Fernandes, C. (2013). Correlations between testicular hemodynamic and sperm characteristics in rams. Brazilian Journal od Veterinary Research and Animal Science, 50(5), 384-395. doi: 10.11606/ issn.2318-3659.v50i5p384-395

Bonilla, L., Santos, A. Q., Borges, J., Siqueira, J., Pinho, R., Gurzoni, W. S.,... Guimaraes, J. (2013). Effect of scrotal insulation on physical and morphological semen features in young cattle. Acta Veterinaria Brasilica, 7(4), 311-318. doi: 10.21708/ avb.2013.7.4.3494

Brito, L. F. C., Silva, A. E. D. F., Barbosa, R. T., \& Kastelic, J. P. (2004). Testicular thermoregulation in Bos indicus, crossbred and Bos taurus bulls: relationship with scrotal, testicular vascular cone and testicular morphology, and effects on semen quality and sperm production. Theriogenology, 61(2), 511528. doi: 10.1016/S0093-691X(03)00231-0

Brito, L. F. C., Silva, A. E. D. F., Barbosa, R. T., Unanian, M. M., \& Kastelic, J. P. (2003). Effects of scrotal insulation on sperm production, semen quality, and testicular echotexture in Bos indicus and Bos indicus $\times$ Bos taurus bulls. Animal Reproduction Science, 79(1), 1-15. doi: 10.1016/S0378-4320(03)00082-4

Brito, L. F. C., Silva, A. E. D. F., Rodrigues, L. H., Vieira, F. V., Deragon, L. A. G., \& Kastelic, J. P. (2002). Effect of age and genetic group on characteristics of the scrotum, testes and testicular vascular cones, and on sperm production and semen quality in AI bulls in Brazil. Theriogenology, 58(6), 1175-1186. doi: 10.1016/S0093-691X(02)00921-4

Bustos-Obregon, E. (2007). Dano testicular por hipoxia simulada. International Journal of Morphology, 25(1), 173. doi: 10.4067/S0717-95022007000100022

Caviglione, J. H., Kiihl, L. R. B.; Caramori, P. H.; Oliveira, D. (2000). Cartas climáticas do Paraná. Londrina: IAPAR.

Chenoweth, P., Hopkins, F. M., Spitzer, J. C., \& Larsen, R. E. (2010). Guidelines for using the bull breeding soundness evaluation form. Clinical Theriogenology, 2(1), 43-50.
Chou, Y., \& Yao, L. (2009). Automatic diagnostic system of electrical equipment using infrared thermography. Proceedings of the International Conference of Soft Computing and Pattern Recognition, First International Conference of Soft Computing and Pattern Recognition.Malaca, Malasia.

Colégio Brasileiro de Reprodução Animal (2013). Manual para exame andrológico e avaliação de sêmen animal (3a. ed.). Belo Horizonte: CBRA.

Fernandes, C. E., Dode, M. A. N., Pereira, D., \& Silva, A. E. D. F. (2008). Effects of scrotal insulation in Nellore bulls (Bos taurus indicus) on seminal quality and its relationship with in vitro fertilizing ability. Theriogenology, 70(9), 1560-1568. doi: 10.1016/j. theriogenology.2008.07.005

Freneau, G. E., Chenoweth, P. J., Ellis, R., \& Rupp, G. (2010). Sperm morphology of beef bulls evaluated by two different methods. Animal Reproduction Science, 118(2), 176-181. doi: 10.1016/j. anireprosci.2009.08.015

Hamilton, T., Mota Mendes, C., Castro, L., Assis, P., Felipe Perez Siqueira, A., Carvalho Delgado, J. de,... Assumpção, M. E. (2016). Evaluation of lasting effects of heat stress on sperm profile and oxidative status of ram semen and epididymal sperm. Oxidative Medicine and Cellular Longevity, 2016, 1687657. doi: 10.1155/2016/1687657

Herzog, K., \& Bollwein, H. (2007). Application of doppler ultrasonography in cattle reproduction. Reproduction in Domestic Animals, 42(s2), 51-58. doi: 10.1111/j.1439-0531.2007.00903.X

Horn, M. M., Moraes, J. C. F., \& Galina, C. S. (1999). Bulls semen quality of Aberdeen Angus and Brangus-Ibagé breeds after experimental testicular degeneration induced by dexamethasone. Ciência Rural, 29(3), 523-526. doi: 10.1590/S010384781999000300024

Kastelic, J. P. (2014). Understanding and evaluating bovine testes. Theriogenology, 81(1), 18-23. doi: 10.1016/j.theriogenology.2013.09.001

Kastelic, J. P., \& Brito, L. F. C. (2012). Ultrasonography for monitoring reproductive function in the bull. Reproduction in Domestic Animals, 47(s3), 45-51. doi: 10.1111/j.1439-0531.2012.02042.x

Kastelic, J. P., Cook, R. B., Coulter, G. H., \& Saacke, R. G. (1996). Insulating the scrotal neck affects semen quality and scrotal/testicular temperatures in the bull. Theriogenology, 45(5), 935-942. doi: 10.1016/0093691X(96)00023-4 
Kastelic, J. P., Coulter, G. H., \& Cook, R. B. (1995). Scrotal surface, subcutaneous, intratesticular, and intraepididymal temperatures in bulls. Theriogenology, 44(1), 147-152. doi: 10.1016/0093691X(95)00155-2

Kastelic, J. P., Wilde, R. E., Rizzoto, G., \& Thundathil, J. C. (2017). Hyperthermia and not hypoxia may reduce sperm motility and morphology following testicular hyperthermia. Veterinari Medicina, 62(8), 437-442. doi: 10.17221/124/2016-VETMED

Knížková, I., Kunc, P., Gürdil, G., Pinar, Y., \& Selvi, K. (2007). Applications of infrared thermography in animal production. Journal of Faculty of Agriculture, 22(3), 329-336. doi: 10.7161/ anajas.2007.22.3.329-336

Lunstra, D. D., \& Coulter, G. H. (1997). Relationship between scrotal infrared temperature patterns and natural-mating fertility in beef bulls2. Journal of Animal Sci, 75(3), 767-774. doi: $10.2527 / 1997.753767 \mathrm{x}$

Menegassi, S. R. O., Barcellos, J. O. J., Dias, E. A., Koetz, C., Pereira, G. R., Peripolli, V.,... Lopes, F. G. (2015). Scrotal infrared digital thermography as a predictor of seasonal effects on sperm traits in Braford bulls. International Journal of Biometeorology, 59(3), 357364. doi: 10.1007/s00484-014-0847-z

Menegassi, S. R. O., Pereira, G. R., Bremm, C., Koetz, C., Lopes, F. G., Fiorentini, E. C.,... Barcellos, J. O. J. (2016). Effects of ambient air temperature, humidity, and wind speed on seminal traits in Braford and Nellore bulls at the Brazilian Pantanal. International Journal of Biometeorology, 60(11), 1787-1794. doi: 10.1007/s00484-016-1167-2

Menegassi, S. R. O., Pereira, G. R., Dias, E. A., Rocha, M. K., Carvalho, H. R., Koetz, C.,... Barcellos, J. O. J. (2017). Infrared thermography as a noninvasive method to assess scrotal insulation on sperm production in beef bulls. Andrologia, 50(3), e12904. doi: $10.1111 /$ and.12904

Moreira, E. P., Moura, A. de A. A., Araujo, A. A. de. (2001). Efeitos da insulação escrotal sobre a biometria testicular e parâmetros seminais em carneiros da raça Santa Inês criados no estado do Ceará. Revista Brasileira de Zootecnia, 30(6), 8. doi: 10.1590/S1516-35982001000700007

Parkinson, T. J. (1987). Seasonal variations in semen quality of bulls: correlations with environmental temperature. Veterinary Record, 120(20), 479-482. doi: $10.1136 /$ vr.120.20.479
Paul, C., Teng, S., \& Saunders, P. T. K. (2009). A single, mild, transient scrotal heat stress causes hypoxia and oxidative stress in mouse testes, which induces germ cell death. Biology of Reproduction, 80(5), 913-919. doi: 10.1095/biolreprod.108.071779

Pezzini, T. G., Sartori, R., Silva, T. A. de S. N., McManus, C., \& Mariante, A. da S. (2006). Características seminais de touros Curraleiros e Holandeses submetidos à insulação escrotal. Pesquisa Agropecuária Brasileira, 41(5), 6. doi: 10.1590/ S0100-204X2006000500020

Polguj, M. S., Jędrzejewski, K., \& Topol, M. (2010). Arterial supply of human and bovine testes: a topographic and morphometric comparison study. Folia Morphologica, 69(4), 225-231. doi: 10.5603. FM

Prabhakar, J., Chimbombi, J., Malmgren, L., Fredriksson, G., \& Madej, A. (1990). Effects on testosterone and LH concentrations of induced testicular degeneration in bulls. Acta Veterinaria Scandinavica, 31(4), 505507. doi: 10.1186/s13028

Rahman, M. B., Vandaele, L., Rijsselaere, T., Maes, D., Hoogewijs, M., Frijters, A.,... Van Soom, A. (2011). Scrotal insulation and its relationship to abnormal morphology, chromatin protamination and nuclear shape of spermatozoa in Holstein-Friesian and Belgian Blue bulls. Theriogenology, 76(7), 12461257. doi: 10.1016/j.theriogenology.2011.05.031

Ruediger, F., George, M., Chacur, M., Carlos Platzeck, F., Alves, E., Oba, E.,... Ramos, A. (2016). Digital infrared thermography of the scrotum, semen quality, serum testosterone levels in Nellore bulls (Bos taurus indicus) and their correlation with climatic factors. Semina: Ciências Agrárias, 37(1), 221-232. doi: 10.5433/1679-0359.2016v37n1p221

Setchell, B. (1998). The parkes lecture heat and the testis. Journal of Reproduction and Fertility, 114(2), 179194. doi: 10.1530/jrf.0.1140179

Setchell, B. (2006). The effect of heat on the testes of mammals. Animal Reproduction, 3(2), 8191. doi: 10.21451/1984 Retrieved from http:// www.cbra.org.br/portal/downloads/publicacoes/ animalreproduction/issues/download/v $3 \mathrm{n} 2 /$ AR132\%20Setchell\%20pag81-91.pdf

Setchell, B. P. (1978). The mammalian testis. London: Elek Books/Ithaca: Cornell University Press.

Vogler, C. J., Bame, J. H., DeJarnette, J. M., McGilliard, M. L., \& Saacke, R. G. (1993). Effects of elevated testicular temperature on morphology 
characteristics of ejaculated spermatozoa in the bovine. Theriogenology, 40(6), 1207-1219. doi: 10.1016/0093-691X(93)90291-C

Waites, G. M. H. (1970). Temperature regulation and the testis. In A. D. Johnson, W. R. Gomes, \& N. L. Vandemark (Eds.), Development, anatomy, and physiology (pp. 241-279). New York: Academic Press.
Welsh, J. T. H., \& Johnson, B. H. (1981). Stressinduced alterations in secretion of corticosteroids, progesterone, luteinizing hormone, and testosterone in bulls. Endocrinology, 109(1), 185-190. doi: 10.1210/endo-109-1-185 